\title{
Clofibrate treatment in pigs: Effects on parameters critical with respect to peroxisome proliferator-induced hepatocarcinogenesis in rodents
}

\author{
Sebastian Luci ${ }^{1}$, Beatrice Giemsa1 ${ }^{1}$ Gerd Hause ${ }^{2}$, Holger Kluge ${ }^{1}$ and \\ Klaus Eder*1
}

Address: ${ }^{1}$ Institut für Agrar- und Ernährungswissenschaften, Martin-Luther-Universität Halle-Wittenberg, Emil-Abderhalden-Strasse 26, D-06108 Halle (Saale), Germany and 'Biozentrum, Martin-Luther-Universität Halle-Wittenberg, Weinbergweg 22, 06120 Halle (Saale), Germany

Email: Sebastian Luci - sebastian.luci@landw.uni-halle.de; Beatrice Giemsa - beatrice.giemsa@landw.uni-halle.de; Gerd Hause - gerd.hause@biozentrum.uni-halle.de; Holger Kluge - holger.kluge@landw.uni-halle.de; Klaus Eder* - klaus.eder@landw.unihalle.de

* Corresponding author

Published: 16 April 2007

BMC Pharmacology 2007, 7:6 doi:10.1186/147|-2210-7-6

This article is available from: http://www.biomedcentral.com/I47/-22/0/7/6

(c) 2007 Luci et al; licensee BioMed Central Ltd.

This is an Open Access article distributed under the terms of the Creative Commons Attribution License (http://creativecommons.org/licenses/by/2.0), which permits unrestricted use, distribution, and reproduction in any medium, provided the original work is properly cited.

\begin{abstract}
Background: In rodents treatment with fibrates causes hepatocarcinogenesis, probably as a result of oxidative stress and an impaired balance between apoptosis and cell proliferation in the liver. There is some debate whether fibrates could also induce liver cancer in species not responsive to peroxisome proliferation. In this study the effect of clofibrate treatment on peroxisome proliferation, production of oxidative stress, gene expression of pro- and anti-apoptotic genes and proto-oncogenes was investigated in the liver of pigs, a non-proliferating species.

Results: Pigs treated with clofibrate had heavier livers (+16\%), higher peroxisome counts (+61\%), higher mRNA concentration of acyl-CoA oxidase $(+66 \%)$, a higher activity of catalase $(+41 \%)$ but lower concentrations of hydrogen peroxide $(-32 \%)$ in the liver than control pigs $(P<0.05)$; concentrations of lipid peroxidation products (thiobarbituric acid-reactive substances, conjugated dienes) and total and reduced glutathione in the liver did not differ between both groups. Clofibrate treated pigs also had higher hepatic mRNA concentrations of bax and the proto-oncogenes c-myc and $c-j u n$ and a lower mRNA concentration of bcl- $X_{L}$ than control pigs $(P<0.05)$.

Conclusion: The data of this study show that clofibrate treatment induces moderate peroxisome proliferation but does not cause oxidative stress in the liver of pigs. Gene expression analysis indicates that clofibrate treatment did not inhibit but rather stimulated apoptosis in the liver of these animals. It is also shown that clofibrate increases the expression of the proto-oncogenes cmyc and c-jun in the liver, an event which could be critical with respect to carcinogenesis. As the extent of peroxisome proliferation by clofibrate was similar to that observed in humans, the pig can be regarded as a useful model for investigating the effects of peroxisome proliferators on liver function and hepatocarcinogenesis.
\end{abstract}




\section{Background}

Peroxisome proliferators (PPs) comprise a diverse group of chemicals, including pharmaceuticals, industrial chemicals, endogenous fatty acids and eicosanoids. They bind to and activate the peroxisome proliferator-activated receptor (PPAR)- $\alpha$, a transcription factor belonging to the nuclear hormone receptor superfamily [1]. Activation of PPAR $\alpha$ causes an increase in the transcription of genes related to fatty acid transport across the cell membrane, intracellular lipid trafficking, mitochondrial and peroxisomal fatty acid uptake, and both mitochondrial and peroxisomal fatty acid $\beta$-oxidation [2]. Administration of PPs to rats and mice typically causes hepatic peroxisome proliferation, hypertrophy, hyperplasia, and hepatocarcinogenesis $[3,4]$. PPAR $\alpha$-induced hepatocarcinogenesis in rats and mice may be mainly due to an increased oxidative stress caused by peroxisome proliferation and an alteration of the balance between apoptosis and cell proliferation [5,6]. Treatment with PPs such as fibrates causes a 15 to 20-fold up-regulation of acyl-CoA oxidase (ACO) and other peroxisomal oxidases that lead to the production of hydrogen peroxide $\left(\mathrm{H}_{2} \mathrm{O}_{2}\right)$ which under normal noninduced circumstances can be detoxified by catalase $[7,8]$. Catalase induction increases only approximately twofold in response to PPAR $\alpha$ agonists in rodents, and the activity of glutathione peroxidase is often depressed following long term administration of PPs $[9,10]$. The capacity of the $\mathrm{H}_{2} \mathrm{O}_{2}$-degrading enzymes therefore may be insufficient to detoxify the large increase in $\mathrm{H}_{2} \mathrm{O}_{2}$. Increased cellular $\mathrm{H}_{2} \mathrm{O}_{2}$ could also react with metals and generate highly reactive hydroxyl radicals that could damage DNA, proteins or lipids [7]. Indeed, oxidatively damaged DNA and peroxide-modified lipids have been found in hepatocytes of rats treated with PPs [11-13]. Activation of PPAR $\alpha$ also leads to increases in hepatocellular proliferation and inhibition of apoptosis, and when this occurs in DNAdamaged cells, it is thought to lead to proliferation of initiated cells progressing to liver tumour $[14,15]$. That PPAR $\alpha$ is required to mediate hepatocarcinogenesis by PPs has been demonstrated in studies with PPAR $\alpha$-null mice that are refractory to this in response to long term administration of PPs $[15,16]$.

It is well known that non-human primates and humans are only weakly responsive to peroxisome proliferation in comparison to rodents $[17,18]$. Nevertheless, there is considerable controversy as to whether the administration of drugs which are ligands for PPAR $\alpha$ to humans causes liver cancer. This is significant because PPAR $\alpha$ agonists such as fibrates have been in clinical use for the treatment of hyperlipidaemias for many years. The data regarding the ability of fibrates to cause peroxisome proliferation in humans are diverse. Examination of liver biopsy samples from patients receiving therapeutic doses of PPAR $\alpha$ agonists showed a slight increase in peroxisome counts [19], while others showed no increase [20,21]. In non-human primates, administration of clofibrate induced a moderate, dose-dependent peroxisome proliferation [22-24]. It is therefore conceivable that cellular events induced by PPs related to hepatocarcinogenesis in rodents could occur also in non-proliferating species, albeit probably less pronounced than in rodents.

Pigs, like humans and non-human primates, are a nonproliferating species [25]. They may therefore be a valuable model for investigating the effects of PPs on peroxisome proliferation and related processes. To our knowledge, the effect of fibrates on parameters related to hepatocarcinogenesis has not yet been investigated in pigs. We therefore treated pigs with clofibrate and determined hepatic weight, number of peroxisomes and ACO expression to provide information about the potency of fibrates to induce peroxisome proliferation in pigs. We also considered the antioxidant status of the pigs (mRNA concentrations and activities of various antioxidant enzymes including catalase, generation of $\mathrm{H}_{2} \mathrm{O}_{2}$ in the liver, concentrations of lipid peroxidation products) to find out whether clofibrate causes oxidative stress in pig liver. In order to ascertain whether clofibrate treatment could affect the balance between cell proliferation and apoptosis we determined mRNA concentrations of proand anti-apoptotic genes, namely bax, bcl- $\mathrm{X}_{\mathrm{L}}$ and $\mathrm{p} 53$ tumour suppressor gene. It has been shown that the nuclear factor $\kappa \mathrm{B}(\mathrm{NF}-\mathrm{\kappa B})$ pathway is important in the activation of genes that regulate cell proliferation and apoptosis in various cell types [26,27]. It was shown recently that NF- $\mathrm{KB}$ contributes to the proliferative and apoptotic changes that occur in liver in response to fibrates [28]. More recently, it has been demonstrated that the p50 subunit of the NF-KB family is necessary for the promotion of hepatocarcinogenesis by PPs [29]. To find out whether clofibrate treatment activated NF-KB in pig liver, we determined the mRNA concentration of tumor necrosis factor $\alpha(\mathrm{TNF} \alpha)$, a target gene of NF-KB which has also been identified as a suppressor of apoptosis and an inducer of DNA synthesis [30,31]. In rat liver and in mouse liver epithelial cells, treatment with the PPAR $\alpha$ agonist WY-14,643 strongly up-regulated gene expression of various proto-oncogenes including c-fos, c-jun and cmyc [32-35]. In mouse liver cells these changes were followed by enhanced DNA synthesis, and it has been concluded that this could play an important role in tumour promotion by PPs [33]. Whether PPs stimulate expression of proto-oncogenes in pigs has not yet been investigated. We therefore also determined gene expression of c-myc, cjun and c-fos in liver of pigs treated with clofibrate, which could be critical with respect to hepatocarcinogenesis. 


\section{Results}

Due to the controlled feeding system, diet intake during the whole experimental period was identical in both groups of pigs, being $696 \pm 7 \mathrm{~g} / \mathrm{d}$ in average of the whole period. Final body weights of the pigs on day 29 did not differ between the control group and the group treated with clofibrate $(26.0 \pm 1.5 \mathrm{~kg}$ for control pigs $v s .25 .2 \pm 1.2$ $\mathrm{kg}$ for pigs treated with clofibrate, $n=9$ in each group). Pigs treated with clofibrate had higher liver weights $(+16 \%$ in absolute terms, $+19 \%$ in relative terms, expressed per kg body weight), higher peroxisome counts in the liver $(+61 \%)(\mathrm{P}<0.05$, Table 1$)$. Relative mRNA concentration of PPAR $\alpha$ in liver did not differ between both groups of pigs (control: $1.00 \pm 0.38$; clofibrate: 0.92 $\pm 0.20, \mathrm{n}=9$, means $\pm \mathrm{SD}$ ) but pigs treated with clofibrate had a higher relative mRNA concentration of ACO in the liver $(+66 \%)$ than control pigs $(\mathrm{P}<0.05$, Table 1$)$.

As reference values for the expression of enzyme activities, we determined concentrations of protein in liver homogenate and liver cytosol. Protein concentration in liver homogenate did not differ between both groups of pigs (control: $20.8 \pm 5.9 \mathrm{mg} / \mathrm{g}$ liver; clofibrate: $21.1 \pm 5.8 \mathrm{mg} /$ g liver, $\mathrm{n}=9$, means $\pm \mathrm{SD}$ ); protein concentration in liver cytosol was higher in pigs treated with clofibrate than in control pigs (control: $27.2 \pm 2.3 \mathrm{mg} / \mathrm{g}$ liver; clofibrate: $30.4 \pm 3.0 \mathrm{mg} / \mathrm{g}$ liver, $\mathrm{n}=9$, means $\pm \mathrm{SD}, \mathrm{P}<0.05$ ). Pigs treated with clofibrate had higher mRNA concentrations and activities of superoxide dismutase (SOD) $(+77 \%$ and $+128 \%$, respectively) and catalase $(+72 \%$ and $+41 \%$, respectively) in the liver than control pigs $(\mathrm{P}<0.05$, Table 2 ). In contrast, mRNA concentration and activity of glutathione peroxidase (GSH-Px) in liver were reduced by $26 \%$ and $15 \%$, respectively, in pigs treated with clofibrate compared to control pigs $(\mathrm{P}<0.05$, Table 2$)$. mRNA concentration and activity of glutathione S-transferase (GST) in liver cytosol and concentrations of total and reduced glutathione in liver homogenate did not differ between both groups of pigs (Table 2). However, the concentration of $\alpha$-tocopherol, both in absolute terms and in relative terms, expressed per mmol of triglycerides + total cholesterol, was lower in the liver of pigs treated with clofibrate than in the liver of control pigs $(-40 \%, \mathrm{P}<0.05)$ (Table 2$)$.

The concentration of $\mathrm{H}_{2} \mathrm{O}_{2}$ in the liver was about $32 \%$ lower in pigs treated with clofibrate than in control pigs ( $\mathrm{P}$ $<0.05$, Table 3 ). Concentrations of lipid peroxidation products, thiobarbituric acid-reactive substances (TBARS) and conjugated dienes did not differ between both groups of pigs, both in absolute terms and in relative terms, expressed per mmol of triglycerides + total cholesterol (Table 3).

Hepatic mRNA concentrations of p53 and c-fos did not differ between pigs treated with clofibrate and control pigs whereas mRNA concentrations of bax, c-jun and c-myc were higher in pigs treated with clofibrate than in control pigs $(\mathrm{P}<0.05$, Fig. 1). Hepatic mRNA concentrations of bcl- $\mathrm{X}_{\mathrm{L}}$ and TNF $\alpha$ were lower in pigs treated with clofibrate than in control pigs $(\mathrm{P}<0.05$, Fig. 1$)$.

\section{Discussion}

To our knowledge, this is the first study to investigate the effect of clofibrate treatment on peroxisome proliferation and parameters that may be related to hepatocarcinogenesis in pigs, a non-proliferating species. As in many other studies dealing with the effects of clofibrate on metabolism in experimental animals, we added clofibrate to the diet. The concentration of clofibrate in the diet of $5 \mathrm{~g}$ per $\mathrm{kg}$ diet was adopted from other studies with pigs $[25,36,37]$. The resulting daily dose of $220 \mathrm{mg}$ per $\mathrm{kg}$ body weight was relatively high compared with doses used in humans for treatment of hyperlipidaemia, which are usually in the range between 25 and $30 \mathrm{mg}$ per $\mathrm{kg}$ body weight.

Analysis of liver weights and number of peroxisomes showed that treatment with clofibrate caused moderate peroxisome proliferation in pigs. The increase in the number of peroxisomes $(+62 \%)$ observed in pigs treated with clofibrate is of a similar order of magnitude as the $50 \%$ increase in liver peroxisome counts observed in humans treated with clofibrate [19]. The extent of the change in peroxisome counts in pigs is modest when compared with that reported for rodents. In rodents, administration of a dose of $200 \mathrm{mg}$ clofibrate per kg body weight, comparable with that used in this study in pigs, resulted in a three- to five-fold increase in peroxisome counts compared with controls [38]. The current study also shows that gene expression of ACO is moderately increased by clofibrate in pigs, which is in close accord with the moderate effect of clofibrate on the peroxisome count. The present study confirms other studies $[25,36,37]$ which have also shown that clofibrate causes only a relatively weak up-regulation of PPAR $\alpha$ target genes in pig liver. The moderate effect of clofibrate on ACO in pigs is in strong contrast to rodents where treatment with PPs causes a 10 to 20-fold increase in ACO expression [35,39]. Up-regulation of ACO in the liver is critical because it leads to increased production of $\mathrm{H}_{2} \mathrm{O}_{2}$ which causes oxidative stress within the cell. In contrast to observations in rodents, pigs treated with clofibrate in this study had not a higher but a lower concentration of $\mathrm{H}_{2} \mathrm{O}_{2}$ in the liver. We assume that this is due to up-regulation of catalase, the key enzyme involved in $\mathrm{H}_{2} \mathrm{O}_{2}$ detoxification. In our study both ACO and catalase were up-regulated by clofibrate to a similar extent. Catalase has a high $\mathrm{H}_{2} \mathrm{O}_{2}$-detoxifying activity and is the rate-limiting enzyme for inhibiting $\mathrm{H}_{2} \mathrm{O}_{2}$ leakage from peroxisomes [40]. The finding that the concentration of $\mathrm{H}_{2} \mathrm{O}_{2}$ was reduced even though the activ- 
Table I: Liver weights, number of peroxisomes and relative acyl-CoA oxidase mRNA concentration in the liver of pigs fed a control diet or a diet supplemented with $5 \mathrm{~g}$ clofibrate per $\mathbf{k g}$ for $\mathbf{2 8}$ days

\begin{tabular}{lll}
\hline Treatment & Control $(n=9)$ & Clofibrate $(n=9)$ \\
\hline Liver weight $(\mathrm{g})$ & $673 \pm 63$ & $779 \pm 63^{*}$ \\
Liver weight (g/kg body weight) & $25.9 \pm 2.2$ & $30.9 \pm 2.6^{*}$ \\
Number of peroxisomes ( $\mathrm{n} / \mathrm{I}, 000$ print) & $366 \pm 67$ & $590 \pm 116^{*}$ \\
Acyl-CoA oxidase mRNA & $1.00 \pm 0.35$ & $1.66 \pm 0.4 I^{*}$ \\
\hline
\end{tabular}

Results are means \pm SD.

*Significantly different from control group $(P<0.05)$

ity of GSH-Px, another $\mathrm{H}_{2} \mathrm{O}_{2}$-detoxifying enzyme localised in cytosol was reduced as well, suggests that the upregulation of catalase was sufficient to eliminate all of the $\mathrm{H}_{2} \mathrm{O}_{2}$ produced in peroxisomes. The finding of a reduced activity of GSH-Px in liver of pigs treated with clofibrate agrees with findings in rodents treated with PPs which also showed a lower activity of that enzyme in the liver $[11,41]$.

Unsaturated fatty acids are susceptible to reactive oxygen species and undergo oxidation. The determination of lipid peroxides such as TBARS or conjugated dienes is therefore a sensible method to detect oxidative stress. Indeed, in hepatocytes of rats treated with PPs, concentrations of lipid peroxidation products were increased due to oxidative stress induced by peroxisome proliferation $[11,42]$. The fact that concentrations of TBARS and conjugated dienes were not increased in the liver of pigs treated with clofibrate indicates that the moderate peroxisome proliferation was not accompanied by oxidative stress. This indication is supported by the observation that the concentration of reduced glutathione in the liver was also not altered in pigs treated with clofibrate when compared with control pigs. Glutathione plays a pivotal role in protecting cells against the noxious effects of oxidant agents, and oxidative stress leads to enhanced oxidation of glutathione, which in turn causes a lower concentration of reduced glutathione and a lower ratio of reduced to oxidized glutathione [43]. Likewise, activity of GST, an enzyme belonging to the phase II enzymes whose reactions include the addition of glutathione to electrophilic molecules as well as the detoxification of organic hydroperoxides, was not changed in pigs treated with clofibrate. This is in contrast to rodents treated with fibrates or other PPs that have a strongly reduced activity of GST in the liver $[44,45]$. As it has been suggested that the reduced GST activity in rodents treated with PPs is the consequence of oxidative stress due to peroxisome proliferation, the finding of an unchanged activity of that enzyme is another indication that oxidative stress did not occur in pigs treated with clofibrate. This indication agrees with a recent study which investigated the effect of high doses of

Table 2: Relative mRNA concentrations and activities of antioxidant enzymes and concentrations of some antioxidants in the liver of pigs fed a control diet or a diet supplemented with $\mathbf{5} \mathrm{g}$ clofibrate per $\mathrm{kg}$ for $\mathbf{2 8}$ days

\begin{tabular}{|c|c|c|}
\hline Treatment & Control $(n=9)$ & Clofibrate $(n=9)$ \\
\hline \multicolumn{3}{|l|}{ Catalase } \\
\hline mRNA concentration & $1.00 \pm 0.49$ & $1.72 \pm 0.58 *$ \\
\hline Activity (U/mg protein) & $0.75 \pm 0.14$ & $1.06 \pm 0.16^{*}$ \\
\hline \multicolumn{3}{|l|}{ Glutathione peroxidase } \\
\hline mRNA concentration & $1.00 \pm 0.17$ & $0.74 \pm 0.18^{*}$ \\
\hline Activity (U/mg protein) & $4.7 \pm 0.8$ & $4.0 \pm 0.4^{*}$ \\
\hline \multicolumn{3}{|l|}{ Glutathione S-transferase } \\
\hline mRNA concentration & $1.00 \pm 0.41$ & $0.90 \pm 0.32$ \\
\hline Activity (U/mg protein) & $0.76 \pm 0.26$ & $0.76 \pm 0.18$ \\
\hline \multicolumn{3}{|l|}{ Superoxide dismutase } \\
\hline mRNA concentration & $1.00 \pm 0.42$ & $1.77 \pm 0.40 *$ \\
\hline Activity (U/mg protein) & $43 \pm 8$ & $97 \pm 13^{*}$ \\
\hline Glutathione, total (nmol/mg protein) & $2.13 \pm 0.51$ & $1.97 \pm 0.90$ \\
\hline Glutathione, reduced (nmol/mg protein) & $1.70 \pm 0.50$ & $1.67 \pm 1.02$ \\
\hline \multicolumn{3}{|l|}{$\alpha$-tocopherol } \\
\hline$(\mathrm{nmol} / \mathrm{g})$ & $14.5 \pm 2.5$ & $8.7 \pm 2.9 *$ \\
\hline [nmol/(mmol triglycerides + cholesterol)] & $2.32 \pm 0.40$ & $1.36 \pm 0.45^{*}$ \\
\hline
\end{tabular}

Results are means \pm SD.

*Significantly different from control group $(P<0.05)$

\#Relative to control (= I.00) 
Table 3: Concentration of hydrogen peroxide and lipid peroxidation products in the liver of pigs fed a control diet or a diet supplemented with $\mathbf{5}$ g clofibrate per kg for 28 days

\begin{tabular}{lll}
\hline Treatment & Control $(n=9)$ & Clofibrate $(n=9)$ \\
\hline $\begin{array}{l}\text { Hydrogen peroxide (fluorescence/g liver) } \\
\begin{array}{l}\text { Thiobarbituric acid-reactive substances } \\
(\mathrm{nmol} / \mathrm{g} \text { liver) }\end{array}\end{array}$ & $29,437 \pm 8,36 \mathrm{I}$ & $20,078 \pm 7,225 *$ \\
$\quad[\mathrm{nmol} / \mathrm{mmol}$ triglycerides + cholesterol)] & $7.2 \pm 1.6$ & $7.7 \pm 2.7$ \\
$\begin{array}{l}\text { Conjugated dienes (nmol/g) } \\
(\mathrm{nmol} / \mathrm{g} \text { liver) }\end{array}$ & $1.15 \pm 0.26$ & $1.20 \pm 0.42$ \\
$\quad[\mathrm{nmol} /(\mathrm{mmol}$ triglycerides + cholesterol)] & $16 \pm 2$ & $16 \pm 2$ \\
\hline
\end{tabular}

Results are means \pm SD.

*Significantly different from control group $(P<0.05)$

fenofibrate and ciprofibrate in cynomolgus monkeys [24]. In that study, clofibrate treatment induced moderate hepatic peroxisome proliferation, similar to that observed in the pigs of the present study, but there was also mini- mal indication of oxidative stress. It is therefore concluded that even high doses of fibrates cause little oxidative stress in the liver of non-proliferating species.

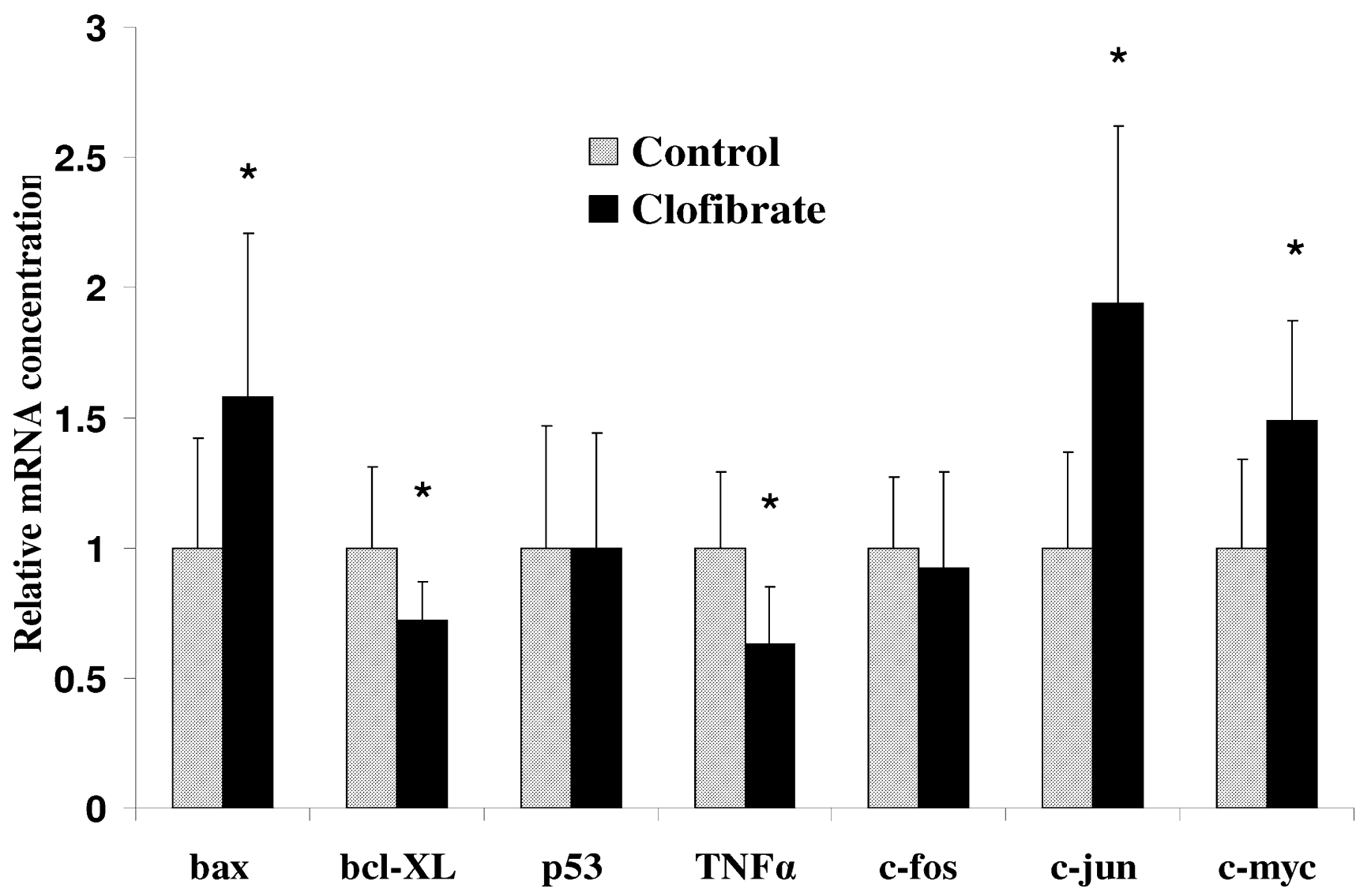

Figure I

Relative mRNA concentrations of pro- and anti-apoptotic genes (bax, bcl- $X_{L}, p 53, T N F \alpha$ ) and proto-oncogenes (c-myc, c-jun, $\mathrm{c}$-fos) in livers of pigs fed a control diet or a diet supplemented with $5 \mathrm{~g}$ clofibrate per $\mathrm{kg}$ for 28 days. All mRNA concentrations were determined by real-time quantitative PCR and normalized to GAPDH. Data are reported as means \pm SD with nine animals per group. Data are expressed relative to mRNA concentrations of control pigs $($ control $=1)$. * Significantly different to control group $(P<0.05)$. 
In the current study, pigs treated with clofibrate had increased hepatic mRNA concentration and activity of SOD, an enzyme that converts superoxide anions into $\mathrm{H}_{2} \mathrm{O}_{2}$ and therefore contributes to increased $\mathrm{H}_{2} \mathrm{O}_{2}$ production. The finding that $\mathrm{H}_{2} \mathrm{O}_{2}$ concentration in the liver was reduced in spite of the increased activity of SOD is another indication that pigs treated with fibrate had a high hepatic $\mathrm{H}_{2} \mathrm{O}_{2}$-detoxifying capacity. Results from other studies dealing with the effects of PPs on hepatic SOD are contradictory. In some studies, treatment of rodents with PPs lowered hepatic activity of SOD $[41,46]$; in others treatment with PPs increased the activity of hepatic SOD $[47,48]$. Moreover, it has been shown that different PPs can have different effects on hepatic activity of SOD, and that there are also differences between mice and hamsters in the effect of PPs on SOD activity [48]. The reason for these contradictory results is unclear and should be investigated further. As SOD is an important constituent of the hepatic antioxidant system, an increased activity of that enzyme observed in pigs treated with clofibrate could contribute to a high antioxidant capacity in the liver of these pigs.

The finding that pigs treated with clofibrate had a reduced concentration of $\alpha$-tocopherol in the liver agrees with those of several other studies in which rodents were treated with PPs $[11,48,49]$. It has been shown that the tocopherol-lowering effect of PPs is stronger in rats than in hamsters, suggesting that there is a correlation with the degree of peroxisome proliferation [48]. It has been suggested that the reduction of hepatic tocopherol concentration is not primarily due to oxidative stress produced by PPs but rather to their hypolipidaemic effect [48]. Tocopherols are transported by lipoproteins within the body and as hypolipidaemic drugs reduce the number of lipoprotein particles in blood, they could also impair vitamin $\mathrm{E}$ transport in the body, i.e. transport of vitamin $\mathrm{E}$ from the intestine to the liver by chylomicrons. The fact that $\alpha$ tocopherol concentration was reduced in the liver of pigs treated with clofibrate although there were no signs of oxidative stress confirms the suggestion that PPs do reduce hepatic vitamin E concentrations independent of oxidative stress.

It has been shown that peroxisome proliferation leads to hepatocellular proliferation and to inhibition of apoptosis, and these processes may contribute to hepatomegaly and to hepatocarcinogenesis observed in rodents treated with PPs $[14,15]$. The present study shows that clofibrate treatment of pigs increases gene expression of the protooncogenes c-jun and c-myc, which are required for entry into the $S$ phase of the cell cycle. These findings are in agreement with recent studies in rodent livers and liver cells in which treatment with WY-14,643 strongly up-regulated gene expression of proto-oncogenes [32-34]. Up- regulation of proto-oncogenes in mouse liver cells was followed by enhanced progression, and it has been suggested that this could play a role in tumour promotion of PPs [32]. Although up-regulation of proto-oncogenes was smaller in pigs treated with fibrates than in rodents [3234 ], increased levels of c-jun and c-myc could have enhanced cell proliferation, which might explain the increased liver mass in pigs treated with clofibrate. Upregulation of proto-oncogenes could be a critical event with respect to tumorigenesis. On the other hand, c-myc can collaborate with other proteins to induce apoptosis and sensitize cells to a variety of apoptotic triggers [50,51]. In order to find out whether clofibrate treatment in pigs could have altered apoptosis, we determined mRNA concentrations of bax, bcl- $\mathrm{X}_{\mathrm{L}}$ and p53 in the liver. Genes of the bcl-2 family have anti-apoptotic effects, which is antagonized by bax. The bcl-2/bax ratio is a key factor for determining apoptosis. When bcl-2 is expressed excessively, bcl-2-bax heterogenous dimer predominates, thus inhibiting apoptosis [52]. When bax is expressed excessively, bax-bax homogenous dimer or monomer predominates, thus promoting apoptosis. p53 is a tumour suppressor which exerts control over cell cycling by controlling the progression through the G1 phase [53]. Genotoxic stress or DNA damage leads to nuclear accumulation of p53, which in turn activates the transcription of several genes involved in DNA repair or apoptosis, including bcl-2 [54]. We did not directly determine apoptosis in the liver of piglets but the finding that expression of bax was up-regulated in pigs treated with clofibrate while expression of bcl- $\mathrm{X}_{\mathrm{L}}$ was reduced, together with the observation of unchanged p53 expression suggests that apoptosis was not inhibited but could instead have been increased in these pigs. This suggestion agrees with recent studies which have shown that clofibrate induces apoptosis in human and rat hepatoma cells [55-59]. In agreement with our study, a recent study showed that treatment with WY 14,643 up-regulates pro-apoptotic genes and down regulates anti-apoptotic genes in the liver of mice, an effect which did not occur in PPAR $\alpha$-null mice [60]. In that study, it was also demonstrated that PPAR $\alpha$ activation increases the sensitivity of liver towards apoptosis by Jo-2, an inducer of hepatic apoptosis. Therefore, it has been suggested that PPAR $\alpha$ could serve as a pharmacological target in diseases where apoptosis is a contributing feature $[60,61]$.

In a recent study in rats it was found that NF-KB is activated by WY-14,643, probably due to oxidative stress caused by peroxisome proliferation [62]. It has been demonstrated that NF-KB is essential for inducing cell proliferation and hepatocarcinogenesis in rodents treated with fibrates $[28,29]$. The finding that mRNA concentration of $\mathrm{TNF} \alpha$, a target gene of NF- $\mathrm{KB}$, was reduced in liver of pigs treated with clofibrate compared to control pigs indicates 
that clofibrate did not activate the NF-KB pathway in these animals. This finding may be related to the observation that clofibrate treatment did not cause oxidative stress in pigs, in contrast to rats. The finding that WY-14,643 did not activate the NF-KB pathway in hamsters either [62] suggests that PPs activate NF-KB only in species that are responsive to $\mathrm{PP}$ induced hepatocarcinogenesis.

\section{Conclusion}

Treatment with clofibrate at doses higher than those used for hypolipidaemic treatment in humans causes moderate peroxisome proliferation in the liver of pigs. Determination of the concentration of $\mathrm{H}_{2} \mathrm{O}_{2}$ and lipid peroxidation products indicates that this did not produce oxidative stress. Determination of mRNA concentrations of proand anti-apoptotic genes in the liver indicates that clofibrate treatment did also not inhibit but rather stimulated apoptosis in these animals. Up-regulation of the protooncogenes c-myc and c-jun in the liver, however, could be a critical event with respect to carcinogenesis, which deserves further investigation in future studies. As the extent of peroxisome proliferation by clofibrate was similar to that observed in humans, the pig can be regarded as a useful model for the investigating the effects of PPs on liver function and hepatocarcinogenesis.

\section{Methods}

\section{Animals and treatments}

Eighteen male 8-week-old crossbred pigs [(German Landrace $\times$ Large White) $\times$ Pietrain] were kept in a room under controlled conditions at $23 \pm 2{ }^{\circ} \mathrm{C}$ and $55 \pm 5 \%$ relative humidity with light from 0600 to $1800 \mathrm{~h}$. One day before the start of the experimental feeding period the pigs were weighed and randomly assigned to two groups with body weights of $12.0 \pm 1.1 \mathrm{~kg}$ in the control group and $11.9 \pm 0.6 \mathrm{~kg}$ in the treatment group. Both groups of pigs received a nutritionally adequate dry diet for growing pigs (according to [63]) containing (in $\mathrm{g} / \mathrm{kg}$ ) wheat (400), soybean meal (230), wheat bran (150), barley (100), sunflower oil (90) and mineral premix including L-lysine, DL-methionine and L-threonine (30). This diet contained 14.4 MJ metabolizable energy and $185 \mathrm{~g}$ crude protein per $\mathrm{kg}$. The whole daily amount of diet was administered once at $8.00 \mathrm{~h}$. Diet intake was controlled, and each animal in the experiment was offered an identical amount of diet per day. The amount of diet administered was about $15 \%$ below that consumed ad-libitum by pigs of a similar weight (as assessed in a previous study). Therefore, the diet offered was completely taken up by all pigs in the experiment. During feeding period, the amount of diet offered each day was increased continuously from 400 to $1,200 \mathrm{~g}$. Pigs of both groups received the same diet. However, pigs of the treatment group were given additionally $5 \mathrm{~g}$ clofibrate per $\mathrm{kg}$ diet which was freshly given onto the diet on each day. The pigs had free access to water via nip- ple drinking systems. The experimental diets were administered for $28 \mathrm{~d}$. All experimental procedures described followed established guidelines for the care and use of laboratory animals and were approved by the local veterinary office.

\section{Sample collection}

After completion of the feeding period the piglets were captive-bolt stunned and exsanguinated. Four hours before euthanasia each pig was fed its respective diet. After killing, blood was collected into heparinized polyethylene tubes. Plasma was obtained by centrifugation of the blood $\left(1,100 \times \mathrm{g} ; 10 \mathrm{~min} ; 4^{\circ} \mathrm{C}\right)$. The liver was dissected and weighed and samples were stored at $-80^{\circ} \mathrm{C}$ until analysis. For preparation of liver homogenate, one $\mathrm{g}$ of liver was homogenized in $10 \mathrm{~mL}$ of $0.1 \mathrm{M}$ phosphate buffer, pH 7.4, containing 0.25 M sucrose using a Potter-Elvehjem homogenizer. Homogenates were centrifuged at $1,000 \times \mathrm{g}$ for $10 \mathrm{~min}$ at $4{ }^{\circ} \mathrm{C}$ and the supernatant was centrifuged at $15,000 \times \mathrm{g}$ for $15 \mathrm{~min}$ again. The supernatant of that centrifugation was collected and centrifuged at $105,000 \times \mathrm{g}$ for $60 \mathrm{~min}$ to yield the cytosolic fraction. Liver homogenates and cytosolic fraction were stored at $20^{\circ} \mathrm{C}$ for further analysis. Protein concentrations of liver homogenates and cytosol were determined with the bicinchoninic acid reagent according to the supplier's protocol (Interchim, Montelucon, France) using bovine serum albumin as the standard.

\section{RT-PCR analysis}

Total RNA from liver tissue was isolated by TRIzol reagent (Invitrogen, Karlsruhe, Germany) following the manufacturer's protocol, resuspended in diethyl pyrocarbonatetreated water and stored at $-80^{\circ} \mathrm{C}$ until use. The concentration and purity of total RNA was determined by ultraviolet absorbance at 260 and $280 \mathrm{~nm}$ (SpectraFluor Plus; Tecan, Crailsheim, Germany). The quality of all RNA samples was assessed by agarose gel electrophoresis. cDNA was prepared from total RNA $(1.2 \mu \mathrm{g})$ by reverse transcription using M-MuLV Reverse Transcriptase (MBI Fermentas, St. Leon-Rot, Germany) and oligo(dT) $)_{18}$ primers (Operon Biotechnologies, Cologne, Germany). The mRNA concentration of genes was measured by realtime detection PCR using SYBR ${ }^{\oplus}$ Green I and a MJ Research Opticon system (Biozym Diagnostik GmbH, Oldendorf, Germany). Realtime detection PCR was performed with 1.25 U Taq DNA polymerase (Promega, Mannheim, Germany), $500 \mu \mathrm{M}$ dNTPs and $26.7 \mathrm{pmol}$ of the specific primers (Operon Biotechnologies, Cologne, Germany; Table 4). Annealing temperature for all primers was $60^{\circ} \mathrm{C}$. Amplification efficiencies for all primer pairs were determined by template dilution series. Calculation of the relative mRNA concentration was made using the amplification efficiencies and the $\mathrm{C}_{\mathrm{t}}$ values [64]. Glyceraldehyde 3-phosphate dehydro- 
genase (GAPDH) was used as housekeeping gene for normalization.

\section{Enzyme assays}

SOD in liver cytosol was determined with pyrogallol as the substrate [65]. One unit of SOD activity is defined as the amount of enzyme required to inhibit the autoxidation of pyrogallol by $50 \%$. The activity of GSH-Px in liver cytosol was determined with t-butyl hydroperoxide as substrate [66]. One unit of GSH-Px activity is defined as one $\mu \mathrm{mol}$ reduced $\beta$-nicotinamide adenine dinucleotide phosphate oxidized per min. The activity of GST was determined using 1-chloro-2,4-dinitrobenzene as substrate [67]. One unit of GST is defined as one nmol substrate consumed per min. Catalase activity in liver homogenate was determined using hydrogen peroxide as substrate [68]. One unit of catalase activity is defined as the amount consuming $1 \mathrm{mmol}$ hydrogen peroxide per min. GSH concentration in liver homogenates was determined according to Griffith [69].

\section{Determination of conjugated dienes, TBARS, $\alpha$ - tocopherol, cholesterol and triglycerides in the liver}

Lipids from liver were extracted using a mixture of n-hexane and isopropanol $(3: 2, \mathrm{v} / \mathrm{v})$. After drying the lipid extracts, $1 \mathrm{mg}$ of extract was dissolved in $1 \mathrm{ml} \mathrm{n}$-hexane. The concentrations of conjugated dienes were calculated by using the molar extinction coefficient for conjugated dienes at $234 \mathrm{~nm}\left(\varepsilon=29,500 \mathrm{~mol} \times \mathrm{cm}^{-1}\right)$. The concentrations of TBARS were measured with thiobarbituric acid as reagent in a fluorimetric assay [70]. Concentration of $\alpha$ tocopherol in liver tissue was determined by HPLC with fluorescence detection [70]. For determination of triglycerides and total cholesterol, an aliquot of the lipid extract was dried, and the dried lipids were dissolved with Triton $\mathrm{X}-100$ [71]. The concentrations of cholesterol and triglycerides were determined using enzymatic kits (Cat.-No. 113009990314 for cholesterol and Cat.-No. 157609990314 for triglycerides, Ecoline $\mathrm{S}^{+}$, DiaSys, Holzheim, Germany).

\section{Determination of $\mathrm{H}_{2} \mathrm{O}_{2}$}

To determine the $\mathrm{H}_{2} \mathrm{O}_{2}$ content in liver homogenates, a method [72] described for cell culture systems was modified, using dihydrorhodamine 123 (DHR) as substrate. Homogenates were incubated with $27.5 \mu \mathrm{M}$ DHR for $1 \mathrm{~h}$ at $37^{\circ} \mathrm{C}$ in a final volume of $400 \mu \mathrm{l}$. After incubation, the fluorescence of rhodamine 123, the oxidation product of DHR, was measured (excitation wavelength: $485 \mathrm{~nm}$, emission wavelength: $538 \mathrm{~nm}$ ). As previously shown [73], this test is specific for $\mathrm{H}_{2} \mathrm{O}_{2}$ as DHR is specifially oxidized by $\mathrm{H}_{2} \mathrm{O}_{2}$.

\section{Transmission electron microscopy}

Small liver segments of three animals per group were fixed immediately after dissection of the liver with 3\% glutaraldehyde in $0.1 \mathrm{M}$ sodium cacodylate buffer (SCB, $\mathrm{pH}$ 7.2) for 3 hours at room temperature, washed with $\mathrm{SCB}$, postfixed with $1 \%$ osmiumtetroxide in $\mathrm{SCB}$, dehydrated in a graded ethanol series, and embedded in epoxy resin [74]. The material was sectioned with an ultramicrotome $\mathrm{S}$ (Leica, Bensheim, Germany). Ultrathin sections (80 nm) were transferred to coated copper grids and poststained with uranyl acetate and lead citrate. The sections were observed with an EM 900 transmission electron microscope (Zeiss SMT, Oberkochen, Germany) at an acceleration voltage of $80 \mathrm{kV}$. Electron micrographs were taken with a slow scan camera (TRS, Dünzelbach, Germany).

Table 4: Sequences of specific primers used for RT-PCR

\begin{tabular}{|c|c|c|c|}
\hline Gene (NCBI Genbank) & Forward Primer & Reverse Primer & Size, bp \\
\hline ACO (AFI85048) & CTCGCAGACCCAGATGAAAT & TCCAAGCCTCGAAGATGAGT & 218 \\
\hline $\operatorname{bax}($ A 606301$)$ & CGAACTGATCAGGACCATCA & ACAGCCCATCTTCTTCCAGA & 190 \\
\hline bcl- $X_{L}(N M \quad 2 \mid 4285)$ & GAAACCCCTAGTGCCATCAA & GGGACGTCAGGTCACTGAAT & 196 \\
\hline Catalase (NM 21430I) & CAGCTTTAGTGCTCCCGAAC & AGATGACCCGCAATGTTCTC & 180 \\
\hline c-fos ( $(\underline{Y \mid 4808})$ & CTGACACACTCCAAGCGGTA & СTTCTCCTTCAGGTTGG & 209 \\
\hline c-jun (NM 213880) & CAGAGCATGACCCTGAACCT & TTCTTGGGGCATAGGAACTG & 200 \\
\hline c-myc (NM 001005I54) & AATGTCTTGGAACGCCAGAG & CAACTGTTCTCGCCTCTTCC & 204 \\
\hline GAPDH (AF0I7079) & $\begin{array}{l}\text { AGGGGCTCTCCAGAACATCA } \\
\text { TCC }\end{array}$ & $\begin{array}{l}\text { TCGCGTGCTCTTGCTGGGGT } \\
\text { TGG }\end{array}$ & 446 \\
\hline GSH-Px (NM 21420I) & CAAGAATGGGGAGATCCTGA & GATAAACTTGGGGTCGGTCA & 190 \\
\hline GST (NM 214300) & TTTTTGCCAACCCAGAAGAC & GGGGTGTCAAATACGCAATC & 246 \\
\hline p53 (NM 2|4|45) & GCGAGTATTTCACCCTCCAG & TCAGGCCСTTCTCTCTTGAA & 199 \\
\hline PPAR $\alpha$ (DQ437887) & CAGCCTCCAGCCCСTCGTC & $\begin{array}{l}\text { GCGGTCTCGGCATCTTCTAG } \\
\text { G }\end{array}$ & 381 \\
\hline SOD (AF396674) & TCCATGTCCATCAGTTTGGA & CTGCCCAAGTCATCTGGTTT & 250 \\
\hline TNF $\alpha(\underline{X 57321})$ & ССССТGTCСАTСССТTTATT & AAGCCCCAGTTCCAATTCTT & 200 \\
\hline
\end{tabular}

Abbreviations: ACO, acyl-CoA oxidase; GAPDH, glyceraldehyde-3-phosphate dehydrogenase; GSH-Px, glutathione peroxidase; GST, glutathione Stransferase; SOD, superoxide dismutase; TNF $\alpha$, tumor necrosis factor $\alpha$. 
Peroxisomes were counted in 1,000 different regions per liver sample for each animal at a screen $(12,000$-fold magnification).

\section{Statistics}

The results were analyzed using Minitab (State College, $\mathrm{Pa}, \mathrm{USA}$ ) statistical software (release 13). Statistical significance of differences between control group and treatment group was evaluated using Student's t-test. Mean values were considered significantly different for $\mathrm{P}<0.05$.

\section{List of abbreviations}

ACO, acyl-CoA oxidase; DHR, dihydrorhodamine; GAPDH, glyceraldehyde 3-phosphate dehydrogenase; GSH-Px, glutathione peroxidase; GST, glutathione Stransferase; NF-KB, nuclear factor KB; PPAR $\alpha$, peroxisome proliferator-activated receptor $\alpha$; PPs, peroxisome proliferators; SCB, sodium cacodylate buffer; SOD, superoxide dismutase; TBARS, thiobarbituric acid-reactive substances; TNF $\alpha$, tumor necrosis factor $\alpha$.

\section{Authors' contributions}

SL and BG carried out the feeding experiments, performed the analyses and helped to draft the manuscript.

GH determined peroxisome count in the liver by transmission electrone microscopy.

HK participated in the design of the study and in the interpretation of the results and supervised the animal experiment.

KE conceived the study and its design, coordinated work, participated in the interpretation of the results, and prepared the manuscript.

All authors read and approved the final manuscript.

\section{Acknowledgements}

The authors thank Bettina König for critical discussion of the manuscript. S. L. was supported by a grant from Land Sachsen-Anhalt.

\section{References}

I. Schoonjans K, Staels B, Auwerx J: The peroxisome proliferator activated receptors (PPARs) and their effects on lipid metabolism and adipocyte differentiation. Biochim Biophys Acta 1996, I 302:93-109.

2. Mandard S, Muller M, Kersten S: Peroxisome proliferator-activated receptor $\alpha$ target genes. Cell Mol Life Sci 2004, 6 I:393-4I6.

3. Reddy JK, Rao S, Moody DE: Hepatocellular carcinomas in acatalasemic mice treated with nafenopin, a hypolipidemic peroxisome proliferator. Cancer Res 1976, 36:1211-1217.

4. Reddy JK, Azarnoff DL, Hignite CE: Hypolipidaemic hepatic peroxisome proliferators form a novel class of chemical carcinogens. Nature 1980, 283:397-398.

5. Gonzalez FJ, Peters JM, Cattley RC: Mechanism of action of the nongenotoxic peroxisome proliferators: role of the peroxisome proliferator-activator receptor- $\alpha$. J Natl Cancer Inst 1998, 90:1702-1709.
6. Peters JM, Cheung C, Gonzalez F): Peroxisome proliferator-activated receptor- $\alpha$ and liver cancer: where do we stand? J Mol Med 2005, 83:774-785.

7. Yeldandi AV, Rao MS, Reddy JK: Hydrogen peroxide generation in peroxisome proliferator-induced oncogenesis. Mutat Res 2000, 448: I59-177.

8. Ammerschlaeger M, Beigel J, Klein K-U, Müller SO: Characterization of the species-specifity of peroxisome proliferators in rats anf human hepatocytes. Toxicol Sci 2004, 78:229-240.

9. Nemali MR, Reddy MK, Usuda N, Reddy PG, Comeau LD, Rao MS, Reddy JK: Differential induction and regulation of peroxisomal enzymes: predictive value of peroxisome proliferation in identifying certain nonmutagenic carcinogens. Toxicol Appl Pharmacol 1989, 97:72-87.

10. Conway JG, Popp JA: Effect of the hepatocarcinogenic peroxisome proliferator $W y-14,643$ in vivo: no increase in ethane exhalation or hepatic conjugated dienes. Toxicol Appl Pharmacol 1995, I 35:229-236.

II. Conway JG, Tomaszewski KE, Olson MJ, Cattley RC, Marsman DS, Popp JA: Relationship of oxidative damage to the hepatocarcinogenicity of the peroxisome proliferators di(2-ethylhexyl)phthalate and Wy-14,643. Carcinogenesis 1989, 10:513-519.

12. Kasai H, Okada Y, Nishimura S, Rao MS, Reddy JK: Formation of 8hydroxydeoxyguanosine in liver DNA of rats following longterm exposure to a peroxisome proliferators. Cancer Res 1989, 49:2603-2605.

13. Takagi A, Sai K, Umemura T, Hasegawa R, Kurokawa Y: Relationship between hepatic peroxisome proliferation and 8 hydroxydeoxyguanosine formation in liver DNA of rats following long-term exposure to three peroxisome proliferators; di(2-ethylhexyl) phthalate, aluminium clofibrate and simfibrate. Cancer Lett 1990, 53:33-38.

14. Roberts RA: Non-genotoxic hepatocarcinogenesis: suppression of apoptosis by peroxisome proliferators. Ann N Y Acad Sci 1996, 804:588-6II.

15. Peters JM, Cattley RC, Gonzalez FJ: Role of PPAR $\alpha$ in the mechanism of action of the nongenotoxic carcinogen and peroxisome proliferator Wy-14,643. Carcinogenesis 1997, | 8:2029-2033.

16. Roberts RA, James NH, Hasmall SC, Holden PR, Lambe K, Macdonald N, West D, Woodyatt NJ, Whitcome D: Apoptosis and proliferation in nongenotoxic carcinogenesis: species differences and role of PPAR $\alpha$. Toxicol Lett 2000, I I 2:49-57.

17. Eacho PI, Foxworthy PS, Johnson WD, Hoover DM, White SL: Hepatic peroxisomal changes induced by a tetrazole-substituted alkoxyacetophenone in rats and comparison with other species. Toxicol Appl Pharmacol 1986, 83:430-437.

18. Orton TC, Adam HK, Bentley M, Holloway B, Tucker MJ: Clobuzarit: species differences in the morphological and biochemical response of the liver following chronic administration. Toxicol Appl Pharmacol 1984, 73:I38-I5I.

19. Hanefeld M, Kemmer C, Kadner E: Relationship between morphological changes and lipid-lowering action of p-chlorphenoxyisobutyric acid (CPIB) on hepatic mitochondria and peroxisomes in man. Atherosclerosis 1983, 46:239-246.

20. De La Iglesia FA, Lewis JE, Buchanan RA, Macus EL, McMahon G: Light and electron microscopy of liver in hyperlipoproteinemic patients under long-term gemfibrozil treatment. Atherosclerosis 1982, 43:19-37.

21. Blumcke S, Schwartzkopff W, Lobeck H, Edmondson NA, Prentice DE, Blane GF: Influence of fenofibrate on cellular and subcellular liver structure in hyperlipidemic patients. Atherosclerosis 1983, 46:105-116.

22. Lalwani ND, Reddy MK, Ghosh S, Barnard SD, Molello JA, Reddy JK: Induction of fatty acid $\beta$-oxidation and peroxisome proliferation in the liver of rhesus monkeys by DL-040, a new hypolipidemic agent. Biochem Pharmacol 1985, 34:3473-3482.

23. Reddy JK, Lalwani ND, Oureshi SA, Reddy MK, Moehle CM: Induction of hepatic peroxisome proliferation in nonrodent species, including primates. Am J Pathol I984, I | 4: I7|-I83.

24. Hoivik DJ, Qualls CW Jr, Mirabile RC, Cariello NF, Kimbrough CL, Colton HM, Anderson SP, Santostefano MJ, Morgan RJ, Dahl RR, Brown AR, Zhao Z, Mudd PN Jr, Oliver WB Jr, Brown HHR, Miller RT: Fibrates induce hepatic peroxisome and mitochondrial proliferation without overt evidence of cellular proliferation 
and oxidative stress in cynomolgus monkeys. Carcinogenesis 2004, 25: 1757-1769.

25. Cheon Y, Nara TY, Band MR, Beever JE, Wallig MA, Nakamura MT: Induction of overlapping genes by fasting and a peroxisome proliferator in pigs: evidence of functional PPAR $\alpha$ in nonproliferating species. Am J Physiol Regul Integr Comp Physiol 2005, 288:RI525-|535.

26. Barkett M, Gilmore TD: Control of apoptosis by Rel/NF-kappaB transcription factors. Onocogene 1995, I 8:6910-6924.

27. DeMartin R, Schmid JA, Hoferwarbinek R: The NF-kappaB/Rel family of transcription factors in oncogenic transformation and apoptosis. Mutat Res 1999, 437:23I-243.

28. Tharappel JC, Nalca A, Owens AB, Ghabrial L, Konz EC, Glauert HP. Spear BT: Cell proliferation and apoptosis are altered in mice deficient in the NF-kappaB p50 subunit after treatment with the peroxisome proliferator ciprofibrate. Toxicol Sci 2003, 75:300-308.

29. Glauert HP, Eyigor A, Tharappel JC, Cooper S, Lee EY, Spear BT: Inhibition of hepatocarcinogenesis by the deletion of the p50 subunit of NF-KB in mice administered the peroxisome proliferator Wy-14,643. Toxicol Sci 2006, 90:331-336.

30. Rolfe M, James NH, Roberts RA: Tumour necrosis factor $\alpha$ (TNF $\alpha)$ suppresses apoptosis and induces DNA synthesis in rodent hepatocytes: a mediator of the hepatocarcinogenicity of peroxisome proliferators? Carcinogenesis 1997, I 8:2277-2280.

31. Holden PR, Hasmall SC, James NH, West DR, Brindle RD, Gonzalez F], Peters JM, Roberts RA: Tumour necrosis factor $\alpha$ (TNF $\alpha$ ): role in suppression of apoptosis by the peroxisome proliferator nafenopin. Cell Mol Biol 2000, 46:29-39.

32. Ledwith BJ, Johnson TE, Wagner LK, Pauley CJ, Manam S, Galloway SM, Nichols WW: Growth regulation by peroxisome proliferators: opposing activities in early and late GI. Cancer Res 1996 56:3257-3264.

33. Ledwith BJ, Manam S, Troilo P, Joslyn DJ, Galloway SM, Nichols WW: Activation of immediate-early gene expression by peroxisome proliferators in vitro. Mol Carcinog 1993, 8:20-27.

34. Miller RT, Glover SE, Stewart WS, Corton JC, Popp JA, Cattley RC: Effect on the expression of c-met, c-myc and PPAR-alpha in liver and liver tumors from rats chronically exposed to the hepatocarcinogenic peroxisome proliferator WY-I4,643. Carcinogenesis 1996, I7:1337-1341.

35. Cherkaoui-Malki M, Meyer K, Cao WQ, Latruffe N, Yeldandi AV, Rao MS, Bradfield CA, Reddy JK: Identification of novel peroxisome proliferator-activated receptor $\alpha$ (PPAR $\alpha)$ target genes in mouse liver using cDNA microarray analysis. Gene Expr 200I, 9:291-304

36. Yu XX, Odle J, Drackley JK: Differential induction of peroxisomal $\beta$-oxidation enzymes by clofibric acid and aspirin in piglet tissues. Am J Physiol Regul Integr Comp Physiol 200I, 28I:RI553-I56I.

37. Peffer $\mathrm{PL}$, Lin $X$, Odle J: Hepatic $\beta$-oxidation and carnitine palmitoyltransferase $I$ in neonatal pigs after dietary treatments of clofibric acid, isoproterenol, and medium-chain triglycerides. Am J Physiol Regul Integr Comp Physiol 2005 288:RI5I8-RI524.

38. Anthony LE, Schmucker DL, Mooney JS, Jones AL: A quantitative analysis of fine structure and drug metabolism in livers of clofibrate-treated young adult and retired breeder rats. Lipid Res 1978, 19:154-165.

39. He WS, Nara TY, Nakamura MT: Delayed induction of delta-6 and delta-5 desaturases by a peroxisome proliferators. Biochem Biophys Res Commun 2002, 299:832-838.

40. Deisseroth A, Dounce AL: Catalase: Physical and chemical properties, mechanism of catalysis, and physiologic role. Physiol Rev 1970, 50:319-375.

4I. Dhaunsi GS, Singh I, Orak JK, Singh AK. Antioxidant enzymes in ciprofibrate-induced oxidative stress. Carcinogenesis 1994, I5:1923-1930.

42. Marsman DS, Goldsworthy TL, Popp JA: Contrasting hepatocytic peroxisome proliferation, lipofuscin accumulation and cell turnover for the hepatocarcinogens $W y-14,643$ and clofibric acid. Carcinogenesis 1992, 13:1011-1017.

43. Sies $\mathrm{H}$ : Glutathione and its role in cellular functions. Free Radic Biol Med 1999, 27:916-921.
44. O'Brien ML, Cunningham ML, Spear BT, Glauert HP: Effects of peroxisome proliferators on glutathione and glutathione related enzymes in rats and hamsters. Toxicol Appl Pharmacol 200I, I7I:27-37.

45. Seo KW, Kim KB, Kim YJ, Choi JY, Lee KT, Choi KS: Comparison of oxidative stress and change of xenobiotic metabolizing enzymes induced by phtalates in rats. Food Chem Toxicol 2004, 42:107-114

46. Cai Y, Appelkvist EL, DePierre JW: Hepatic oxidative stress and related defenses during treatment of mice with acetylsalicylic acid and other peroxisome proliferators. J Biochem Toxicol 1995, 10:87-94.

47. Arnaiz SL, Travacio M, Llesuy S, Boveris A: Hydrogen peroxide metabolism during peroxisome proliferation by fenofibrate. Biochim Biophys Acta 1995, 1272:175-180.

48. O'Brien ML, Twaroski TP, Cunningham ML, Glauert HP, Spear BT: Effects of peroxisome proliferators on antioxidant enzymes and antioxidant vitamins in rats and hamsters. Toxicol Sci $200 \mathrm{I}$ 60:27I-278

49. Glauert HP, Srinivasan S, Tatum VL, Chen LC, Saxon DM, Lay LT, Borges T, Baker M, Chen LH, Robertson LW, Chow CK: Effects of the peroxisome proliferators ciprofibrate and perfluorodecanoic acid on hepatic cellular antioxidants and lipid peroxidation in rats. Biochem Pharmacol 1992, 43: I353-1359.

50. Lutz W, Fulda S, Jeremias I, Debatin KM, Schwab M: MycN and IFNgamma cooperate in apoptosis of human neuroblastoma cells. Oncogene 1998, 17:339-346.

51. Prendergast GC: Mechanisms of apoptosis by c-Myc. Oncogene 1999, 18:2967-2987.

52. Oltvai ZN, Milliman CL, Korsmeyer SJ: Bcl-2 heterodimerizes in vivo with a conserved homolog, Bax, that accelerates programmed cell death. Cell 1993, 74:609-619.

53. Van Gijssel HE, Maassen CB, Mulder GJ, Meerman JH: p53 protein expression by hepatocarcinogens in the rat liver and its potential role in mitoinhibition of normal hepatocytes as a mechanism of hepatic tumour promotion. Carcinogenesis 1997 , I 8:1027-1033.

54. Muller M, Strand S, Hug H, Heinemann EM, Walczak H, Hofmann WJ, Stremmel W, Krammer PH, Galle PR: Drug-induced apoptosis in hepatoma cells is mediated by the CD95 (APO-I/Fas) receptor/ligand system and involves activation of wild-type p53. J Clin Invest 1997, 99:403-4I3.

55. Canuto RA, Muzio G, Maggiora M, Trombetta A, Martinasso G, Autelli R, Costelli P, Bonelli G, Baccino FM: Apoptosis induced by clofibrate in Yoshida AH-130 hepatoma cells: role of HMGCoA reductase. J Lipid Res 2003, 44:56-64.

56. Canuto RA, Muzio G, Maggiora M, Autelli R, Barbiero G, Costelli P. Bonelli G, Baccino FM: Rapid and extensive lethal action of clofibrate on hepatoma cells in vitro. Cell Death Differ 1997, 4:224-232.

57. Canuto RA, Muzio G, Bonelli G, Maggiora M, Autelli R, Barbiero G, Costelli P, Brossa O, Baccino FM: Peroxisome proliferators induce apoptosis in hepatoma cells. Cancer Detect Prev 1998, 22:357-366.

58. Passilly P, Jannin B, Hassell SJ, Latruffe N: Human HepG2 and rat Fao hepatic-derived cell lines show different responses to ciprofibrate, a peroxisome proliferator: analysis by flow cytometry. Exp Cell Res 1996, 223:436-442.

59. Goll V, Viollon-Abadie C, Nicod L, Richert L: Peroxisome proliferators induce apoptosis and decrease DNA synthesis in hepatoma cell lines. Hum Exp Toxicol 2000, 19:193-202.

60. Xiao S, Anderson SP, Swanson C, Bahnemann R, Voss KA, Stauber AJ Corton JC: Activation of peroxisome proliferator-activated receptor alpha enhances apoptosis in the mouse liver. Toxicol Sci 2006, 92:368-377.

61. Martinasso G, Oraldi M, Trombetta A, Maggiora M, Bertetto O, Canuto RA, Muzio G: Involvement of PPARs in Cell Proliferation and Apoptosis in Human Colon Cancer Specimens and in Normal and Cancer Cell Lines. PPAR Res 2007 in press. Article ID934I6

62. Tharappel JC, Cunningham ML, Spear BT, Glauert HP: Differential activation of hepatic NF-kappaB in rats and hamsters by the peroxisome proliferators $\mathrm{Wy}-14,643$, gemfibrozil, and dibutyl phthalate. Toxicol Sci 200I, 62:20-27.

63. National Research Council (Ed): Nutrient Requirement of Swine. Tenth Revised Edition Washington DC: National Academie of Sciences; 1998. 
64. Pfaffl MW: A new mathematical model for relative quantification in real-time RT-PCR. Nucleic Acids Res 200I, 29:e45.

65. Marklund S, Marklund G: Involvement of the superoxide anion radical in the autoxidation of pyrogallol and a convenient assay for superoxide dismutase. Eur JBiochem 1974, 47:469-474.

66. Paglia DE, Valentine WN: Studies on the quantitative and qualitative characterization of erythrocyte glutathione peroxidase. J Lab Clin Med 1967, 70:158-169.

67. Habig WH, Pabst MJ, Jakoby WB: Glutathione S-transferases. The first enzymatic step in mercapturic acid formation. J Biol Chem 1974, 249:7130-7139.

68. Aebi HE: Catalase. In Methods of Enzymatic Analysis, Band 3 3rd edition. Edited by: Bergmeyer HU. Weinheim, Germany: VCH Verlagsgesellschaft $\mathrm{mbH}$; 1986:273-286.

69. Griffith $\mathrm{OW}$, Meister A: Origin and turnover of mitochondrial glutathione. Proc Natl Acad Sci USA 1985, 82:4668-4672.

70. Brandsch C, Ringseis R, Eder K: High dietary iron concentrations enhance the formation of cholesterol oxidation products in the liver of adult rats fed salmon oil with minimal effects on antioxidant status. J Nutr 2002, 132:2263-2269.

7I. De Hoff JL, Davidson JH, Kritchevsky V: An enzymatic assay for determining free and total cholesterol in tissues. Clin Chem 1978, 24:433-435.

72. Royall JA, Ischiropoulos $\mathrm{H}$ : Evaluation of 2',7'-dichlorofluorescin and dihydrorhodamine 123 as fluorescent probes for intracellular $\mathbf{H}_{2} \mathbf{O}_{2}$ in cultured endothelial cells. Arch Biochem Biophys 1993, 302:348-55.

73. Walrand S, Valeix S, Rodriguez C, Ligot P, Chassagne J, Vasson MP: Flow cytometry study of polymorphonuclear neutrophil oxidative burst: a comparison of three fluorescent probes. Clin Chim Acta 2003, 33 I: 103-1 I0.

74. Spurr AR: A low-viscosity epoxy resin embedding medium for electron microscopy. J Ultrastruct Res 1969, 26:31-43.

\section{Publish with Bio Med Central and every scientist can read your work free of charge}

"BioMed Central will be the most significant development for disseminating the results of biomedical research in our lifetime. "

Sir Paul Nurse, Cancer Research UK

Your research papers will be:

- available free of charge to the entire biomedical community

- peer reviewed and published immediately upon acceptance

- cited in PubMed and archived on PubMed Central

- yours - you keep the copyright

Submit your manuscript here:

http://www.biomedcentral.com/info/publishing_adv.asp
BioMedcentral 